\section{Steric Control of the Coordination Mode of the Salicylaldehyde Thiosemicarbazone Ligand. Syntheses, Structures, and Redox Properties of Ruthenium and Osmium Complexes}

\section{Falguni Basuli, ${ }^{1 a}$ Shie-Ming Peng, ${ }^{1 \mathrm{~b}}$ and Samaresh Bhattacharya*,1a}

Inorganic Chemistry Section, Department of Chemistry, Jadavpur University, Calcutta 700032, India, and Department of Chemistry, National Taiwan University, Taipei, Taiwan, ROC

Received May 1, 1997

\section{Introduction}

The chemistry of transition metal complexes of thiosemicarbazones has been receiving considerable attention largely because of their pharmacological properties. ${ }^{2}$ Thiosemicarbazones usually bind to a metal ion, either in the neutral thione form (1) or in the anionic thiolate form (2), as bidentate N,S-

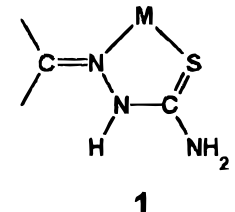

1

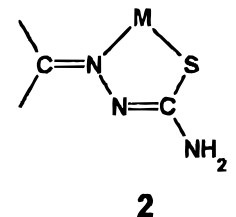

2 donor ligands forming five-membered chelate rings., ${ }^{2,3}$ However, incorporation of a third donor site (D) into these thiosemicarbazone ligands, linked to the carbonylic carbon via one or two intervening atoms, normally results in D,N,S tricoordination (3). ${ }^{2,4,5}$ In this note we report the chemistry of

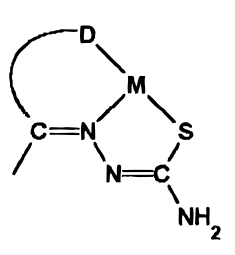

3

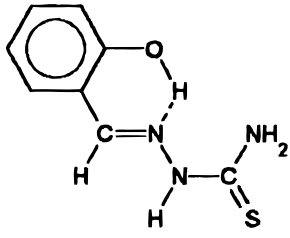

4 two ruthenium and osmium complexes of the same ligand, viz. salicylaldehyde thiosemicarbazone (Hsaltsc, where $\mathrm{H}$ stands for the dissociable proton). Though free Hsaltsc exists in the thione

(1) (a) Jadavpur University. (b) National Taiwan University.

(2) (a) Campbell, M. J. M. Coord. Chem. Rev. 1975, 15, 279. (b) Padhye, S. B.; Kauffman, G. B. Coord. Chem. Rev. 1985, 63, 127. (c) Haiduc, I.; Silvestru, C. Coord. Chem. Rev. 1990, 99, 253. (d) West, D. X.; Padhye, S. B.; Sonawane, P. B. Struct. Bonding 1991, 76, 1. (e) West, D. X.; Liberta, A. E.; Padhye, S. B.; Chikate, R. C.; Sonawane, P. B.; Kumbhar, A. S.; Yerande, R. G. Coord. Chem. Rev. 1993, 123, 49.

(3) Tion, Y. P.; Duan, C. Y.; Lu, Z. L.; You, X. Z.; Fun, H. K.; Kandasamy, S. Polyhedron 1996, 15, 2263.

(4) (a) Souza, P.; Matesanz, I. A.; Fernandez, V. J. Chem. Soc., Dalton Trans. 1996, 3011. (b) Kovala-Demertzi, D.; Domopoulou, A.; Demertzis, M. A.; Valdes-Martinez, J.; Hernandez-Ortega, S.; Espinosa-Perez, G.; West, D. X.; Salberg, M. M.; Bain, G. A.; Bloom, P. D. Polyhedron 1996, 15, 2587. (c) Ali, M. A.; Dey, K. K.; Nazimuddin, M.; Smith, F. E.; Butcher, R. J.; Jasinski, J. P.; Jasinski, J. M. Polyhedron 1996, 15, 3331.

(5) (a) De Bolfo, A.; Smith, T. D.; Boas, J. F.; Pilbrow, J. R. Aust. J. Chem. 1976, 29, 2583. (b) Lu, Z.; White, C.; Rheingold, A. L.; Crabtree, R. H. Inorg. Chem. 1993, 32, 3991. (c) West, D. X.; Yang, Y.-H.; Klein, T. L.; Goldberg, K. I.; Liberta, A. E.; Valdes-Martinez, J.; Toscano, R. A. Polyhedron 1995, 14, 1681. (d) West, D. X.; Yang, Y.-H.; Klein, T. L.; Goldberg, K. I.; Liberta, A. E.; Valdes-Martinez, J.; Hernandez-Ortega, S. Polyhedron 1995, 14, 3051. form (4), ${ }^{6}$ it is known to coordinate as a dianionic tridentate $\mathrm{O}, \mathrm{N}, \mathrm{S}$ donor. ${ }^{5}$ Reaction of Hsaltsc with $\left[\mathrm{M}\left(\mathrm{PPh}_{3}\right)_{3} \mathrm{X}_{2}\right](\mathrm{M}=$ $\mathrm{Ru}, \mathrm{Os} ; \mathrm{X}=\mathrm{Cl}, \mathrm{Br})$ afforded complexes of the type $\left[\mathrm{M}\left(\mathrm{PPh}_{3}\right)_{2}-\right.$ (saltsc $)_{2}$ ] where the salicylaldehyde thiosemicarbazone ligand is coordinated, in spite of having the phenolic oxygen as the potential third donor site, as a bidentate N,S-donor ligand, forming a four-membered chelate ring (5). The steric bulk of

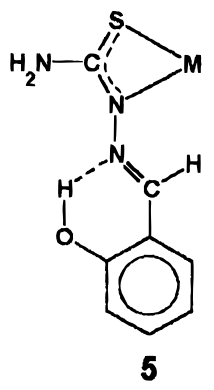

the coligand $\mathrm{PPh}_{3}$ appears to be the driving force for this rather unexpected coordination mode of the salicylaldehyde thiosemicarbazone ligand. The syntheses, characterization, and cyclic voltammetric properties of these two $\left[\mathrm{M}\left(\mathrm{PPh}_{3}\right)_{2}(\mathrm{saltsc})_{2}\right] \mathrm{com}-$ plexes are described here.

\section{Experimental Section}

Materials. $\left[\mathrm{Ru}\left(\mathrm{PPh}_{3}\right)_{3} \mathrm{Cl}_{2}\right]$ and $\left[\mathrm{Os}\left(\mathrm{PPh}_{3}\right)_{3} \mathrm{Br}_{2}\right]$ were synthesized according to reported procedures. ${ }^{7}$ Salicylaldehyde thiosemicarbazone (Hsaltsc) was prepared by reacting equimolar amounts of salicylaldehyde and thiosemicarbazide in hot ethanol. Purification of dichloromethane and preparation of tetraethylammonium perchlorate (TEAP) for electrochemical work were performed as reported in the literature. ${ }^{8}$

Preparation of $\left.\left[\mathbf{R u}\left(\mathbf{P P h}_{3}\right)_{2} \text { (saltsc }\right)_{2}\right]$. To a solution of Hsaltsc (42 $\mathrm{mg}, 0.22 \mathrm{mmol})$ in ethanol $(40 \mathrm{~mL})$ was added $\left[\mathrm{Ru}\left(\mathrm{PPh}_{3}\right)_{3} \mathrm{Cl}_{2}\right](100$ $\mathrm{mg}, 0.10 \mathrm{mmol})$ followed by $\mathrm{NEt}_{3}(0.22 \mathrm{mg}, 0.22 \mathrm{mmol})$. The resulting mixture was stirred for $30 \mathrm{~min}$ at ambient temperature. The yellow precipitate of $\left[\mathrm{Ru}\left(\mathrm{PPh}_{3}\right)_{2}(\mathrm{saltsc})_{2}\right]$ was collected by filtration, washed thoroughly with ethanol, and dried in air. Recrystallization of the crude product from 1:1 dichloromethane-hexane solution gave $\left[\mathrm{Ru}\left(\mathrm{PPh}_{3}\right)_{2}-\right.$ (saltsc $)_{2}$ ] as a golden yellow crystalline solid. Yield: $72 \%$. Anal. Calcd for $\mathrm{C}_{52} \mathrm{H}_{46} \mathrm{~N}_{6} \mathrm{O}_{2} \mathrm{P}_{2} \mathrm{~S}_{2} \mathrm{Ru}$ : C, 61.60; H, 4.54; N, 8.29. Found: C, 61.54; $\mathrm{H}, 4.59 ; \mathrm{N}, 8.26$.

Preparation of $\left[\mathrm{Os}\left(\mathrm{PPh}_{3}\right)_{2}(\mathbf{s a l t s c})_{2}\right]$. This was prepared by following the above procedure (except that stirring was continued for $2 \mathrm{~h}$ at $\left.60{ }^{\circ} \mathrm{C}\right)$ using $\left[\mathrm{Os}\left(\mathrm{PPh}_{3}\right)_{3} \mathrm{Br}_{2}\right]$ instead of $\left[\mathrm{Ru}\left(\mathrm{PPh}_{3}\right)_{3} \mathrm{Cl}_{2}\right]$. Yield: $67 \%$. Anal. Calcd for $\mathrm{C}_{52} \mathrm{H}_{46} \mathrm{~N}_{6} \mathrm{O}_{2} \mathrm{P}_{2} \mathrm{~S}_{2} \mathrm{Os}$ : C, 56.62; H, 4.17; N, 7.62. Found: $\mathrm{C}, 56.54 ; \mathrm{H}, 4.21 ; \mathrm{N}, 7.58$.

Physical Measurements. Microanalyses $(\mathrm{C}, \mathrm{H}, \mathrm{N})$ were performed using a Perkin-Elmer 240C elemental analyzer. IR spectra were obtained on a Perkin-Elmer 783 spectrometer with samples prepared as $\mathrm{KBr}$ pellets. Electronic spectra were recorded on a Simadzu UV1601 spectrophotometer. Magnetic susceptibilities were measured using a PAR 155 vibrating-sample magnetometer. ${ }^{1} \mathrm{H}$ NMR spectra were obtained on a Bruker AC-200 NMR spectrometer using TMS as the internal standard. Electrochemical measurements were made using a PAR model 273 potentiostat. A platinum-disk working electrode, a platinum-wire auxiliary electrode, and an aqueous saturated calomel reference electrode (SCE) were used in a three-electrode configuration. A platinum-wire gauze electrode was used in the coulometric experiments. An RE $0074 \mathrm{X}-\mathrm{Y}$ recorder was used to trace the voltammograms. Electrochemical measurements were made under a dinitrogen

(6) Chattopadhyay, D.; Mazumdar, S. K.; Banerjee, T.; Ghosh, S.; Mak, T. C. W. Acta Crystallogr. 1988, C44, 1025.

(7) (a) Stephenson, T. A.; Wilkinson, G. J. Inorg. Nucl. Chem. 1966, 28, 945. (b) Hoffman, P. R.; Caulton, K. G. J. Am. Chem. Soc. 1975, 97, 4221.

(8) (a) Sawyer, D. T.; Roberts, J. L., Jr. Experimental Electrochemistry for Chemists; Wiley: New York, 1974; pp 167-215. (b) Walter, M.; Ramaley, L. Anal. Chem. 1973, 45, 165. 
Table 1. Crystallographic Data for $\left[\mathrm{Ru}\left(\mathrm{PPh}_{3}\right)_{2}(\mathrm{saltsc})_{2}\right] \cdot 2 \mathrm{CH}_{2} \mathrm{Cl}_{2}$

\begin{tabular}{|c|c|}
\hline empirical formula & $\mathrm{C}_{54} \mathrm{H}_{50} \mathrm{~N}_{6} \mathrm{O}_{2} \mathrm{P}_{2} \mathrm{~S}_{2} \mathrm{Cl}_{4} \mathrm{Ru}$ \\
\hline fw & 1183.97 \\
\hline space group & triclinic $\mathrm{P} \overline{1}$ \\
\hline$a, \AA$ & $14.863(3)$ \\
\hline$b, \AA$ & $14.830(3)$ \\
\hline$c, \AA$ & $16.025(3)$ \\
\hline$\alpha, \operatorname{deg}$ & $65.103(17)$ \\
\hline$\beta, \mathrm{deg}$ & $62.503(17)$ \\
\hline$\gamma, \mathrm{deg}$ & $64.950(18)$ \\
\hline$V, \AA^{3}$ & $2724.5(9)$ \\
\hline$Z$ & 2 \\
\hline$P_{\text {calcd }}, \mathrm{g} \mathrm{cm}^{-3}$ & 1.443 \\
\hline$\rho_{\text {obsd }}, \mathrm{g} \mathrm{cm}^{-3}$ & 1.440 \\
\hline$\lambda, \AA$ & 0.7107 \\
\hline crystal size, $\mathrm{mm}$ & $0.15 \times 0.30 \times 0.35$ \\
\hline$T,{ }^{\circ} \mathrm{C}$ & 25 \\
\hline$\mu, \mathrm{cm}^{-1}$ & 4.528 \\
\hline$R^{a}$ & 0.049 \\
\hline$R_{\mathrm{w}}{ }^{b}$ & 0.049 \\
\hline GOF & 1.68 \\
\hline
\end{tabular}

atmosphere. All electrochemical data were collected at $298 \mathrm{~K}$ and are uncorrected for junction potentials.

Crystallography of $\left[\mathrm{Ru}\left(\mathrm{PPh}_{3}\right)_{2}(\mathrm{saltsc})_{2}\right] \cdot \mathbf{2 C H}_{2} \mathrm{Cl}_{2}$. Single crystals were grown by slow diffusion of hexane into a dichloromethane solution of the complex. Selected crystal data and data collection parameters are given in Table 1. The unit cell dimensions were determined by a least-squares fit of 25 machine-centered reflections $(15.18<2 \theta$ $<27.08^{\circ}$ ). Data were collected on an Enraf-Nonius CAD-4 diffractometer using graphite-monochromated Mo $\mathrm{K} \alpha$ radiation $(\lambda=0.7107$ A) by $\theta-2 \theta$ scans within the angular range $3.0-45.0^{\circ}$. Three standard reflections measured every $3600 \mathrm{~s}$ of $\mathrm{X}$-ray exposure showed no significant intensity variation over the course of data collection. X-ray data reduction and structure solution and refinement were done using the NRCVAX package. The structure was solved by the Patterson method. Final cycles of refinement converged with discrepancy indices of $R=0.049$ and $R_{\mathrm{w}}=0.049$.

\section{Results and Discussion}

Reaction of $\left[\mathrm{Ru}\left(\mathrm{PPh}_{3}\right)_{3} \mathrm{Cl}_{2}\right]$ with Hsaltsc in a 1:2 mole ratio in the presence of $\mathrm{NEt}_{3}$ affords $\left[\mathrm{Ru}\left(\mathrm{PPh}_{3}\right)_{2}(\mathrm{saltsc})_{2}\right]$ in decent yield. It may be noted here that even when a 1:1 mole ratio of the reactants was used, the same bis complex was obtained together with some unreacted $\left[\mathrm{Ru}\left(\mathrm{PPh}_{3}\right)_{3} \mathrm{Cl}_{2}\right]$, as expected. Synthesis of $\left.\left[\mathrm{Os}\left(\mathrm{PPh}_{3}\right)_{2} \text { (saltsc }\right)_{2}\right]$ was achieved similarly, allowing a relatively longer reaction time and a slightly higher temperature. The complexes are diamagnetic, which corresponds to the bivalent state of the metals (low-spin $\mathrm{d}^{6}, S=0$ ) in these complexes.

The molecular structure of $\left[\mathrm{Ru}\left(\mathrm{PPh}_{3}\right)_{2}(\text { saltsc })_{2}\right]$ was determined by X-ray crystallography. A view of the complex molecule is shown in Figure 1, and selected bond distances and angles are listed in Table 2. The two $\mathrm{PPh}_{3}$ ligands are in cis positions as usually observed in bis(triphenylphosphine) complexes of ruthenium(II). ${ }^{9}$ The saltsc ligands are coordinated as shown in 5 with a bite angle of $\sim 66^{\circ}$, causing severe angular distortion of the $\mathrm{RuN}_{2} \mathrm{P}_{2} \mathrm{~S}_{2}$ coordination sphere from ideal octahedral geometry. As a result, the $\mathrm{P} 1-\mathrm{Ru}-\mathrm{N} 1, \mathrm{P} 2-\mathrm{Ru}-$ $\mathrm{N} 4$, and $\mathrm{S} 1-\mathrm{Ru}-\mathrm{S} 2$ angles deviate significantly from linearity. The phenolic hydrogens are hydrogen-bonded to the azomethine nitrogens as in the case of uncoordinated Hsaltsc. ${ }^{6}$ The observed $\mathrm{Ru}-\mathrm{P}$ and $\mathrm{Ru}-\mathrm{S}$ distances are quite normal. ${ }^{\mathrm{a}}$ However, the $\mathrm{Ru}-\mathrm{N}$ distances are a bit longer than what is usually observed, ${ }^{9 \mathrm{c}}$

(9) (a) Pramanik, A.; Bag, N.; Lahiri, G. K.; Chakravorty, A. J. Chem. Soc., Dalton Trans. 1990, 3823. (b) Pierpont, C. G.; Bhattacharya, S. Inorg. Chem. 1991, 30, 1511. (c) Menon, M.; Pramanik, A.; Bag, N.; Chakravorty, A. J. Chem. Soc., Dalton Trans. 1995, 1417.

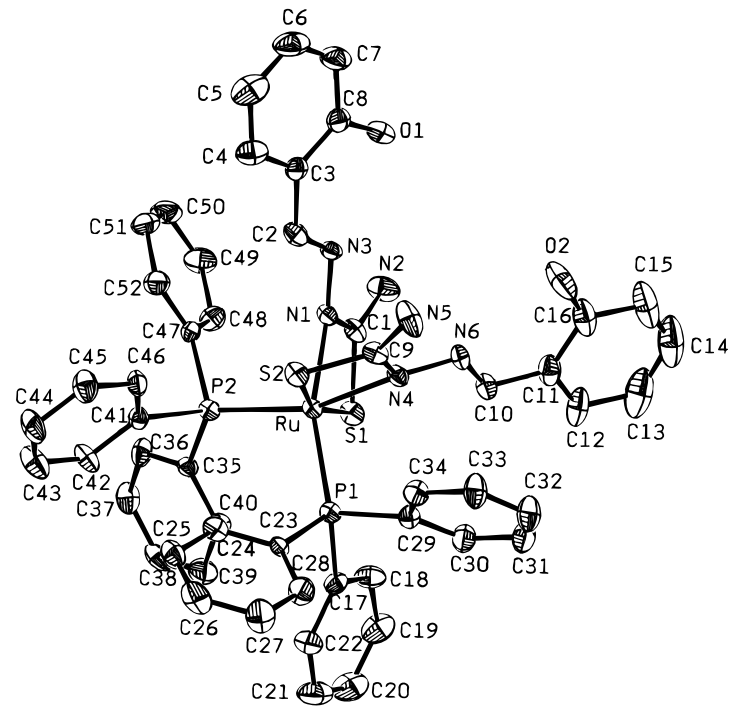

Figure 1. View of the $\left[\mathrm{Ru}\left(\mathrm{PPh}_{3}\right)_{2}(\mathrm{saltsc})_{2}\right]$ molecule.

Table 2. Selected Bond Distances and Bond Angles for $\left[\mathrm{Ru}\left(\mathrm{PPh}_{3}\right)_{2}(\text { saltsc })_{2}\right] \cdot 2 \mathrm{CH}_{2} \mathrm{Cl}_{2}$

\begin{tabular}{llll} 
& \multicolumn{3}{c}{ Bond Distances $(\AA)$} \\
$\mathrm{Ru}-\mathrm{S} 1$ & $2.428(2)$ & $\mathrm{C} 1-\mathrm{S} 1$ & $1.722(8)$ \\
$\mathrm{Ru}-\mathrm{S} 2$ & $2.425(2)$ & $\mathrm{C} 1-\mathrm{N} 1$ & $1.320(9)$ \\
$\mathrm{Ru}-\mathrm{P} 1$ & $2.325(2)$ & $\mathrm{C} 1-\mathrm{N} 2$ & $1.344(9)$ \\
$\mathrm{Ru}-\mathrm{P} 2$ & $2.321(2)$ & $\mathrm{C} 2-\mathrm{N} 3$ & $1.283(10)$ \\
$\mathrm{Ru}-\mathrm{N} 1$ & $2.152(6)$ & $\mathrm{C} 9-\mathrm{S} 2$ & $1.719(8)$ \\
$\mathrm{Ru}-\mathrm{N} 4$ & $2.152(6)$ & $\mathrm{C} 9-\mathrm{N} 4$ & $1.319(9)$ \\
& \multicolumn{5}{c}{$\mathrm{C} 9-\mathrm{N} 5$} & $1.333(9)$ \\
& $\mathrm{C} 10-\mathrm{N} 6$ & $1.289(10)$ \\
$\mathrm{S} 1-\mathrm{Ru}-\mathrm{S} 2$ & $161.23(7)$ & $\mathrm{S} 1-\mathrm{Ru}-\mathrm{N} 1$ & \\
$\mathrm{P} 1-\mathrm{Ru}-\mathrm{N} 1$ & $161.90(16)$ & $\mathrm{S} 2-\mathrm{Ru}-\mathrm{N} 4$ & $65.96(16)$ \\
$\mathrm{P} 2-\mathrm{Ru}-\mathrm{N} 4$ & $161.38(16)$ & $\mathrm{P} 1-\mathrm{Ru}-\mathrm{P} 2$ & $105.95(16)$
\end{tabular}

which may be attributed to the strong trans effect of the $\mathrm{PPh}_{3}$ ligands. The $\mathrm{C}-\mathrm{N}$ distances within the chelate ring $(\mathrm{C} 1-\mathrm{N} 1$ and $\mathrm{C} 9-\mathrm{N} 4)$ are shorter than a formal single bond (e.g. $\mathrm{C} 1-$ $\mathrm{N} 2$ and $\mathrm{C} 9-\mathrm{N} 5)$ and longer than a formal double bond (e.g. $\mathrm{C} 2-\mathrm{N} 3$ and $\mathrm{C} 10-\mathrm{N} 6)$. Similarly the $\mathrm{C}-\mathrm{S}$ distances $(\mathrm{C} 1-\mathrm{S} 1$ and $\mathrm{C} 9-\mathrm{S} 2)$ are intermediate between $\mathrm{C}\left(\mathrm{sp}^{2}\right)-\mathrm{S}(1.76 \AA)^{10}$ and $\mathrm{C}=\mathrm{S}(1.63 \AA) .{ }^{11}$ This is in accordance with the resonance possible in the coordinating part of the saltsc ligand as illustrated in 5 .

The structure of $\left[\mathrm{Ru}\left(\mathrm{PPh}_{3}\right)_{2}(\text { saltsc })_{2}\right]$ has a $C_{2}$ symmetry, which is also reflected in the ${ }^{1} \mathrm{H}$ NMR spectrum of this complex recorded in $\mathrm{CDCl}_{3}$ solution. The aromatic region of the spectrum is rather complex due to overlap of signals. However, the spectrum clearly shows the azomethine proton signal at 8.89 ppm, the phenolic proton resonance at $10.48 \mathrm{ppm}$, and the two amine hydrogens at $4.71 \mathrm{ppm}$. The ${ }^{1} \mathrm{H}$ NMR spectrum of [Os$\left(\mathrm{PPh}_{3}\right)_{2}$ (saltsc $\left.)_{2}\right]$ is almost identical to that of the ruthenium complex, indicating that $\left[\mathrm{Os}\left(\mathrm{PPh}_{3}\right)_{2}(\mathrm{saltsc})_{2}\right]$ has a similar structure. Electronic spectra of the $\left[\mathrm{M}\left(\mathrm{PPh}_{3}\right)_{2}(\mathrm{saltsc})_{2}\right] \mathrm{com}-$ plexes in dichloromethane solution show several intense adsorptions in the visible region (Table 3 ) which are probably due to allowed metal-to-ligand charge-transfer transitions.

Cyclic voltammograms of the $\left[\mathrm{M}\left(\mathrm{PPh}_{3}\right)_{2}(\text { saltsc })_{2}\right]$ complexes were recorded in dichloromethane solution. Each complex shows two oxidative responses on the positive side of SCE (Table 3). The oxidation potentials of the osmium complex are lower than those of the ruthenium analogue, as usually

(10) Collins, R. C.; Davis, R. E. Acta Crystallogr., Sect. B 1978, B34, 283. (11) Arjunan, P.; Ramamurthy, V.; Venkatesan, K. Acta Crystallogr., Sect. C 1984, C40, 556. 
Table 3. Electronic Spectral and Cyclic Voltammetric Data

\begin{tabular}{|c|c|c|}
\hline compound & $\begin{array}{l}\text { electronic spectral } \\
\text { data }^{a} \lambda_{\max }, \mathrm{nm} \\
\left(\epsilon, \mathrm{M}^{-1} \mathrm{~cm}^{-1}\right)\end{array}$ & $\begin{array}{l}\text { cyclic voltammetric } \\
\text { data }^{a, b} E_{1 / 2}, \mathrm{~V} \\
\left(\Delta E_{\mathrm{p}}, \mathrm{mV}\right)\end{array}$ \\
\hline$\left[\mathrm{Ru}\left(\mathrm{PPh}_{3}\right)_{2}(\text { saltsc })_{2}\right]$ & $\begin{array}{l}440^{c}(1100), 342(7400), \\
\quad 304^{c}(8900), 266(14700)\end{array}$ & $0.41(60), 1.10^{d}$ \\
\hline$\left[\mathrm{Os}\left(\mathrm{PPh}_{3}\right)_{2}(\mathrm{saltsc})_{2}\right]$ & $\begin{array}{c}475^{c}(1800), 375^{c}(12500) \\
338(21700), 314^{c} \\
(18200), 272(22400)\end{array}$ & $0.21(60), 1.02^{d}$ \\
\hline
\end{tabular}

observed. ${ }^{9 a, 12}$ The first reversible response is assigned to M(II)M(III) oxidation. The one-electron nature of this oxidation was verified by constant-potential coulometry. The oxidized solutions containing $\left[\mathrm{M}^{\mathrm{III}}\left(\mathrm{PPh}_{3}\right)_{2}(\text { saltsc })_{2}\right]^{+}$ions are light green and display voltammograms identical to those of their precursors (except that the $\mathrm{M}(\mathrm{II})-\mathrm{M}(\mathrm{III})$ couple appears as a reductive response). These oxidized solutions are quantitatively converted

(12) (a) Kober, E. M.; Casper, J. V.; Sullivan, B. P.; Meyer, T. J. Inorg. Chem. 1988, 27, 4587. (b) Pramanik, A.; Bag, N.; Lahiri, G. K.; Chakravorty, A. J. Chem. Soc., Dalton Trans. 1992, 101. back to yellow solutions of $\left[\mathrm{M}^{\mathrm{II}}\left(\mathrm{PPh}_{3}\right)_{2}(\mathrm{saltsc})_{2}\right]$ by coulometric reduction. The second response is irreversible and is tentatively assigned to $\mathrm{M}(\mathrm{III})-\mathrm{M}(\mathrm{IV})$ oxidation. The one-electron nature of this oxidation was established by comparing its current height $\left(i_{\mathrm{pa}}\right)$ with that of the $\mathrm{M}(\mathrm{II})-\mathrm{M}(\mathrm{III})$ couple.

Variation of steric bulk of the coligand in order to force O,N,S tricoordination of the salicylaldehyde thiosemicarbazone ligand is currently under investigation. The possibility of using these $\left[\mathrm{M}\left(\mathrm{PPh}_{3}\right)_{2}(\mathrm{saltsc})_{2}\right]$ complexes as precursors for making polynuclear complexes, utilizing the donor atoms on the pendant part of the N,S-coordinated saltsc ligands, is also being explored.

Acknowledgment. Financial assistance received from the Council of Scientific and Industrial Research, New Delhi [Grant No. 01(1408)/96/EMR-II], is gratefully acknowledged, as is financial support from the Third World Academy of Sciences for the purchase of an electrochemical cell system. F.B. thanks the University Grants Commission, New Delhi, for a fellowship.

Supporting Information Available: Tables containing crystal data and details of the structure determination, atomic coordinates, anisotropic thermal parameters, and bond distances and angles (9 pages). Ordering information is given on any current masthead page.

IC9705094 